\title{
„Forradalmi” változások a menedzsment területén
}

\author{
F. NÁDASDI ${ }^{1}$, A. KESZI-SZEREMLEI ${ }^{2}$ \\ 1Dunaújvárosi Egyetem, nadasdi.ferenc@gmail.com \\ ${ }^{2}$ Dunaújvárosi Egyetem, keszi.andrea@gmail.com
}

\begin{abstract}
Absztrakt. A tudomány fejlődése, illetve az eredmények gyakorlati alkalmazása hatalmas változásokat hozott létre a nem-hagyományos területeken is. Kialakult az „egészségipar”. A fizika, kémia, biológia, mikroelektronika stb. eredményei teljesen új diagnosztikai, mütéti, kezelési stb. eljárások létrehozását tették lehetôvé. Kialakult a „pénzipar”. A jelenleg gondot okozó gazdasági válság - megítélésünk szerint - egyik legfontosabb oka a „pénzipar” nem kellően szabályozott múködése. Kialakult a „tudásipar”. Ez a terület magába foglalja az oktatás minden szintjét, és a $K+F+I$ (Kutatás + Fejlesztés + Innováció) területét is. Elemzéseink szerint a társadalom gazdasági fejlódésének jelenleg a legfontosabb tényezője az innováció. Az új tudományos eredmények alapvetố változásokat okoztak a vezetéstudomány területén is. Kialakult a „Management Science”, amely önálló területet hozott létre. Az erőforrások hatékony allokációjához több, hatékony menedzsment módszert is kialakítottak a menedzsment szakértők (pl. Value Analysis, Risk Menedzsment, Six Sigma, TRIZ, Lean módszer stb.).
\end{abstract}

Abstract. Development of the Science and practical application of the results created big changes in the nontradicional areas too. The "Health industry” was developed. The results of the physics, chemistry, biology and mikroelektronics etc. helped to develop some new methods of diagnosis, operation etc. The "money industry" was developed too. Our opinion is, that the most important cause of the economic crisis is a non-regulated well of the "money industry". The "knowledge industry" was developed too. The "knowledge industry" contains all level of teaching and Research + Development + Innovation. Our analyze shows that the Innovation is the most important factor of the economic Development of Society. The new scientific results created big changes in area of the Management. The „Management Science” was developed as an independent area. Some management specialists developed some management methods (eg. Value Analysis, Risk Management, TRIZ, Lean methods etc.) for efficient allocation of sources.

\section{Bevezetés}

A tudomány fejlődése, illetve az eredmények gyakorlati alkalmazása hatalmas változásokat hozott létre a nem-hagyományos területeken is. Kialakult az „egészségipar”. A fizika, kémia, biológia, mikroelektronika stb. eredményei teljesen új diagnosztikai, műtéti, kezelési stb. eljárások létrehozását tették lehetővé. Ezek az eljárások általában nagyon fontos szerepet töltenek be az emberi gyógyításban. Működtetésük gyakran magas szintű, interdiszciplináris, speciális tudást igényelnek, és jellemző a költségigényesség. Mégis, még a gazdaságilag kevésbé „gazdag” országok is - lehetőség szerint - alkalmazzák ezeket az eljárásokat. Kialakult a „pénzipar”. A jelenleg gondot okozó gazdasági válság - megítélésünk szerint - egyik legfontosabb oka a „pénzipar” nem kellően szabályozott működése. A korábbi évtizedekben mintegy 30 \% volt a „Szabadon” áramló pénz, jelenleg ez az érték 
kb. 70 \% -ra növekedett. Ez azt is jelenti, hogy van „szabad” pénz a társadalmak fejlesztésére, de a „pénzipar” hatékony működése érdekében szükség van a megfelelő szabályozásra, ami még csak most van kialakulóban. [2] Kialakult a „tudásipar”. Ez a terület magába foglalja az oktatás minden szintjét, és a K+F+I (Kutatás + Fejlesztés + Innováció) területét is. Megítélésünk szerint szinte minden területen jelentős változások következtek be, felsorolásunk csak példaszerű volt. Elemzéseink szerint a társadalom gazdasági fejlődésének jelenleg a legfontosabb tényezője az innováció. Az innováció egy bonyolult folyamat, mert sokféle igény (vevő, gyártó, kereskedő, állam stb.) igényeit kell kielégíteni az adott terméknek, amelyet a piacon akarunk értékesíteni. Az innovációs folyamatokat jelentősen befolyásolja továbbá az elérhető erőforrások nagyságrendje és sajátosságai. Hazai és nemzetközi elemzések szerint az innovációs ráfordítások mintegy 50 \% -a „kárba vész”, a fejlesztés sikertelen marad. Ezek a változások alapvető változásokat okoztak a vezetéstudomány területén is. Kialakult a „Management Science”, amely önálló területet hozott létre. Gyakran a „Management” szót nem is fordítjuk le magyar nyelvre, csak átírjuk: menedzsment. A menedzsment egyik fő tulajdonsága, hogy optimalizálni kívánja az erőforrások felhasználását. Az erőforrások hatékony allokációjához több, hatékony menedzsment módszert is kialakítottak a szakértők (pl. Value Analysis, Risk Menedzsment, Six Sigma, TRIZ, Lean módszer stb.). A menedzsment „forradalma” egyes területeken gyökeres változásokat hozott: például felgyorsította a termék - és technológiatervezést és fejlesztést, csökkentette a költségeket stb. Az elmúlt évtizedekben a tőke volt a legfontosabb erőforrás. A változások a „tudás tőkét” emelték ki a legfontosabb erőforrássá. A jelenleg folyó „forradalmi” változások új típusú menedzsment alkalmazását igénylik, ez azonban még nem tudatosult a politikai gazdasági döntéshozók gondolkodásában. Az elméleti megközelítés mellett gyakorlati példákat is be kívánunk mutatni dolgozatunk keretén belül. (A következőkben a management kifejezést magyar nyelvű átírással használjuk.)

\section{2. „Forradalom” a menedzsment területén}

Az ipari és a fent említett nem-hagyományos területek „forradalmai” „megrendelőként jelentkeztek a menedzsment művelői felé. A második világháború alatt fejlődött ki az operációkutatás, amely jelentős szerepet játszott a hadi cselekmények fejlesztésében. A II. Világháború után az operációkutatást eredményesen alkalmazták a polgári területeken is. Elsősorban a hálótervezést és a lineáris programozást emeljük ki. Az informatika megjelenése újabb „lökést” adott a menedzsment módszerek fejlődésének. Az informatikai eszközöket egyre szélesebb körben építik be a gépi berendezésekbe, végtermékekbe, használati eszközökbe stb. Ugyanakkor előtérbe került a termék - és technológiatervezés, fejlesztés, a termelésvezetés modernizálása informatikai és menedzsment eszközökkel. A menedzsment módszereket gyakran összekapcsolják az informatikai eszközökkel.

Az egyre modernebb gépi eszközök lehetővé teszik az egyre fejlettebb informatikai eszközök előállítását, amelyek elősegítik az egyre modernebb gépi eszközök létrehozását. A legtöbb menedzsment eszköznél szinte automatikusan megjelenik az informatikai eszközök használata. Jelenleg már nemcsak a számítógép használatáról beszélünk, hanem a számítógépes hálózatokról is. A hálózatoknál megjelentek a különböző műholdas összeköttetések is. 
A „menedzsment forradalom” nagyszámú eszközt hozott létre, amelyek alapvető hatást gyakorolnak a versenyképességre. A probléma azonban abban jelentkezik, hogy a modern menedzsment eszközök „profi” eljárássá fejlődtek ki, megtanulásuk jelentős idő és költségráfordítást igényel. Elemzéseink szerint egyes menedzsment eszközök olyan verseny előnyt biztosítanak az alkalmazóknak, amelyet a nem-alkalmazók más módszerekkel nem tudnak elérni.

Ez a „menedzsment forradalom” egyik titka.

\section{A „forradalmak” hatása a társadalmi - gazdasági folyamatokra}

Forradalomnak nevezzük az innovációs eredmények folyamatos „beépülését” a társadalmi-gazdasági folyamatokba. A „legerősebb” forradalmi folyamat jelenleg az informatikában működik, de hatása „szétterjed” az élet minden területére. Nagyszámú kutatási eredmény áttanulmányozása azt sugallja számunkra, hogy a globalizáció felerősíti az innovációs eredmények szétterjedését.

Egy otthoni számítógépről kényelmesen vezérelhetők a család banki ügyletei, beleértve az esetenként beérkező számlák rendezését is.

Az egészségügyben megjelentek az ipari csúcstechnológiai eszközök: a lézer, a számítógépes daganatfelismerő berendezések, a különleges röntgen készülékek stb. Ugyanakkor a magyar egészségügyben fellelhető a forráshiány, a többhónapos várólista több fontos mütéttípusnál, esetenként higiéniai problémák is felmerülnek stb.

Megjelentek a modern okmányirodák, amelyekben nagyszámú okmány váltható ki, viszonylag gyorsan. Nagy előrelépésnek tekinthető az adóbevallás elektronikus bevallási lehetősége.

Elemzéseink szerint a „forradalmi” innovációs eredmények „beillesztése” a korábbi rendszerekbe nem zavartalan. Ugyanis az új megoldások az új menedzsment módszerek alkalmazását igénylik, de ez általában csak részben, vagy egyáltalán nem valósul meg.

\section{Az innováció és az új menedzsment módszerek találkozásának szükségessége}

Elemzéseink szerint az új menedzsment módszerek alkalmazása meggyorsítja az innovációs folyamatokat, sőt versenyképesebbé teheti az innovációs terméket.

A helyzet az, hogy még a legmodernebb számítógépes tervezési eljárások (CAD, CAM stb.) sem teszi lehetővé a felesleges költségek elkerülését. Ezt csak az értékelemzés által alkalmazott funkcióelemzés teszi lehetővé. [3]

Előtérbe kerül az időtényező szerepe. Például a TRIZ módszer alkalmazásával nagyságrendileg rövidebb idő alatt fejleszthetők ki az új gyártmányok, technológiák, mint más, egyéb módszerek alkalmazásával. 


\section{A menedzsment, mint szakma}

A menedzsment, mint szakma az 1800-as évek végén alakult ki a gyáripar ugrásszerű fejlődésével. A tulajdonosok/vezetők azt tapasztalták, hogy vezetési módszerek alkalmazásával ugyanannyi erőforrással, sokkal jobb eredményeket lehet elérni. Az 1920-as években - Németországban kifejlesztették a REFA módszert, amely jelenleg is a világ egyik legjobb, leghatékonyabb szervezésivezetési iskolája. Német szakértők szerint a REFA alkalmazása jelenleg is mintegy 25 \%-kal növeli az alkalmazó cégek nyereségét. Jellemző, hogy a REFA különböző szintű minősítését - művezetőig bezárólag - kötelező a vezetóknek megszerezniük. A REFA bevezetését az Ipari Minisztérium anyagilag és erkölcsileg is támogatta. Az elmúlt években létrejöttek azok a szakmai tanácsadó cégek, amelyek folyamatosan végzik a módszer bevezetését az ipari vállalatoknál. [5]

Az elmúlt évtizedekben az innováció területén egy új, forradalmi eljárás jelent meg, a TRIZ. A TRIZ (Theory of Inventive Problem Solving) eljárást Genrikh Saulovich Altshuller fejlesztette ki a Szovjetunióban az 1940 - es években.

Megjegyzés: A TRIZ magyar nyelvű elnevezése (az eredeti orosz megnevezésből történő fordítás szerint): Feltalálói feladatok megoldásának elmélete.

A TRIZ eljárást a FORTUNA 500 vállalatai közül többen sikeresen alkalmazzák (például Ford, General Motors, Chrysler, Eastman, Kodak, Exxon, Rockwell International, Procter \& Gamble, Digital Equipment, Xerox, Hewlett Packard, Motorola stb.) rendkívüli eredményességgel. A TRIZ elnevezés mellett használják az ARIZ-t (Algoritm of Inventive Problem Solving; Feltalálói feladatok megoldásának algoritmusa) is. Az ARIZ lényegében a TRIZ megvalósító alrendszerének tekinthető.

\section{A TRIZ hazai és nemzetközi alkalmazásának tapasztalatai}

A TRIZ eljárást a volt Szovjetunióban fejlesztették ki, mégis elsősorban az USA-ban alkalmazzák. Magyarországon a TRIZ eljárásról csak véletlenszerű publikációk találhatóak, az eljárás alkalmazása nem valószínű a magyar tulajdonú magán vagy állami, illetve közösségi szervezeteknél. Orosz és amerikai szakértők szóbeli tájékoztatása szerint a TRIZ eljárás forradalmi előrelépést jelent az innováció területén. Ha az értékelemzést „gazdasági atombombának” nevezték el, akkor a kettő együttes alkalmazása „gazdasági hidrogénbombának” nevezhető. Érdekes jelenség, hogy az amerikai értékelemzők szorgalmazzák a két módszer együttes alkalmazását. Ennek az a magyarázata, hogy az értékelemzés kiválóan mutatja be a funkciók és a funkcióhordozók kapcsolatrendszerét, de az új megoldások megkeresése azonban nem erőssége a módszernek. A TRIZ eljárás „készen” várja a problémák felsorolását, a problémák azonosítása azonban nem mindig egyszerű feladat. Ezért szorgalmazzák az amerikai szakértők a két módszer együttes alkalmazását. [1]

A következőkben az értékelemzés alkalmazásával kapcsolatos elemzéseinket ismertetjük. 


\section{Az értékelemzés alkalmazásának tapasztalatai}

Az értékelemzés módszertanát ismertnek tekintjük, ezért elsősorban azokat a kutatási eredményeket vázoljuk fel, amelyek az alkalmazási területek bővítését jelentik.

Elemzéseink szerint az értékelemzés legfontosabb alkalmazási területei a következők:

- Döntés előkészítő módszer, amely a piaci - műszaki - gazdasági stb. operációs terek egyidejű figyelembe vételét segíti elő, ami elvezethet az optimális változat kiválasztásához.

- Termékfejlesztő módszer, amely a funkcióelemzéssel a felhasználói igények - a korábbi módszerekhez képest - pontosabb leképezését teszik lehetővé. A funkcióköltségek meghatározása nemcsak a piac által elvárt termékteljesítményt foglalja magába, hanem azon funkcióhordozók kiválasztását, amelyek a vevő számára megfelelő költségszintet, az előállítónak megfelelő profitot biztosít.

- Vezetési koncepció és módszer. A módszer alkalmazása lehetővé teszi egy új vezetési koncepció megvalósítását, amely - a korábbi megoldásokhoz képest hatékonyabban - mozgósíthatja a vállalat/vállalkozás erőforrásait és elősegítheti a piaci versenyben való jobb helytállást, a hatékonyabb hosszú távú fejlődést. A team-munka " előhozza" a munkatársakban " szunnyadó" szellemi energiákat, amelyek újabb és újabb ötletekkel járulnak hozzá a múködés megújulásához.

- Tervezési módszer. Az értékelemzés alkalmas mindenféle termék megtervezésére (Value Engineering) úgy, hogy a felesleges ráfordítások már a tervezés fázisában elkerülhetők legyenek. Megfelelő feltételek esetén (piaci információk, gyártási kapacitások, illetve az ezekkel kapcsolatos várható ráfordítások stb.) viszonylag jól előre jelezhető az adott termék piaci sikere vagy kudarca.

Az értékelemzés legfőbb erénye, hogy a fogyasztó/felhasználó vagy állami érdek igényeiből kiindulva meghatározza és elemezze az adott termék funkcióit. A funkcióelemzést követően megvizsgálja a lehetséges funkcióhordozókat és azok költségeit. Így egy adott műszaki megoldásról kiderül, hogy az hogyan elégíti ki a fogyasztó igényeit, és hogy az adott ráfordítások „beleférnek-e” az elérhető piaci árba. Mindez vonatkozik a nagy nemzetközi gazdasági projektekbe való bekapcsolódás eseteire is, vagy a hazai, úgynevezett, beszállítói programokban való részvétel sikeres előkészítési folyamataiban, de alkalmasak az értéktermelési folyamatok elemzésére is.

$\mathrm{Az}$ értékelemzés művelése elsősorban szellemi ráfordítást igényel. A fejlett piacgazdasággal rendelkező országokban (pl. USA, Japán stb.) már a termékfejlesztésnél alkalmazzák a módszert. A ráfordítások átlagosan 10 - 200 - szorosan térülnek meg. Jelenleg az értékelemzés tehát nemcsak költségcsökkentő módszer, hanem a piaci megfelelés egyik leghatékonyabb segítője is. Ezt mai aktualitásként versenyképesség növelésnek lehet nevezni úgy, hogy nemcsak technológiai újításokat alkalmazunk. [6] [8] [9]

\section{Az értékelemzés alkalmazásának lehetősége és feltételei}

Az értékelemzés egyik fontos kiindulási pontja az, hogy nem az értékelemzőkből „formál” szakembereket egy-egy témában, hanem az adott szakma jeles képviselőit „képezi tovább” értékelemzővé. Ezért az értékelemzés folyamatos oktatása alapvetően fontos feladat a módszer elterjesztésénél. Így lehet viszont megnyugtatóan biztosítani, hogy egy-egy tématerület értékelemzését igen járatos szakemberek végezzék, és ne legyen ellentét a téma és az értékelemzés között. 
Ennek a figyelembe vételével lehet felismerni, hogy az értékelemzés miért hatékonyabb, mint a korábban alkalmazott módszerek, és miért lehet minden értéket előállító vagy kezelő tématerületen alkalmazni. Korábban már említettük, hogy az innováció a legnehezebb vállalkozási feladat, mind a vállalkozás, mind a kormánystratégia szintjén. Mégis talán ezen a területen található a legnagyobb fejlődés.

\section{Megjegyzés:}

- Gyakori hiba, hogy az innovatív gazdasági vezetési stílus eleve minden kevéssé ismert technológiát elvet. A fejlődés azonban soha nem áll meg - a piaci igények is állandóan változnak, ezért ügyelni kell az innovációs folyamatok folytonossági tényezőire.

- A versenytől szorongatott vállalkozók, vagy a bonyolult gazdasági folyamatoktól terhelt kormánystratégiai elképzelések számára szimpatikus módszer a piaci helyzeten való javítás adminisztratív formája. Úgy ítéljük meg, hogy az ilyen tendenciák felderítésére és az ellenük való harc megalapozására már - stratégiai szinten is - kiválóan alkalmazható az értékelemzés módszere.

- Szükség esetén az értékelemzés kiválóan alkalmas a külkapcsolatok funkcionális vizsgálatára, ahol csak a közös érdekek jelenthetnek kooperációs alapot, de a munkaerő helyzet elemzésére és a gazdasági befektetések funkcionális vizsgálatára is - megfelelő szakértelemmel jól felhasználható.

\section{Példa az értékelemzés alkalmazására - PEZSGŐGYÁRTÁS ÉRTÉKELEMZÉSE}

A terméktervezési folyamatban osztályról - osztályra halad a folyamat, ahol az egyes részlegek különféle erőforrásokat bocsájtanak ki a projekt elkészítése érdekében. A projekt végén azonban az is kiderülhet, hogy a ráfordítások „elvesztek”, mert a vevők „álma” jelentős mértékben eltér a mérnökök „álmától”, ezért a kifejlesztett termék sikertelen lesz a piacon.

Az értékelemzési projekt team-munkában történik, így a munka real-time rendszerben folyik, tehát még a döntések előtt lehetőség van szakmai egyeztetésre.

A következőkben a Dunaújvárosi Egyetemen elvégzett értékelemzési projektet mutatjuk be.

\subsection{Pezsgőgyártás értékelemzése}

\subsubsection{A projekt célja}

A termékkel szembeni szigorodó elvárások, valamint az egyre inkább gyorsuló technológiaváltások következtében, fontos szerepet kap a technológiai folyamatok műszaki, gazdasági és minőségbiztosítási paramétereinek folyamatos elemzése, valamint fejlesztése.

A pezsgőpalackozás eljárásának értékelemzéséhez kapcsolódó célok a következők:

- a fogyasztói igényeknek való megfelelés

- a gyártásból eredő minőségi problémák megszüntetése

- a múveleti költségek csökkentése

- a technológia anyag- és energiafelhasználásának csökkentése 
- a gyártási főfolyamat vagy berendezés kapacitás kihasználásának javítása

- az emberi erőforrás kapacitás kihasználásának javítása

- a termelékenység fokozása

- a nehéz fizikai munka kiváltása

- egészség-, baleset- és környezetvédelem javítása. [7]

\subsubsection{A projekt tárgya}

Értékelemzésünk tárgya a palackozás folyamata.

A palackozás 5 szakaszra bontható:

- pezsgőelőkészítő

- depalettázó

- mosó-, öblítő

- töltőüzem

- palettázó

\section{Pezsgöelőkészítő:}

Attól függően, hogy a pezsgő milyen technológiával készült, a palackozás is többféleképpen történhet. A pezsgőkészítés 3 technológiája a következő:

Méthode Charmat, tartályban erjesztett pezsgő:

A pezsgő erjesztése nagy űrtartalmú, nyomásálló tartályokban történik. Az erjesztés és seprőn tartás után szűréssel seprőtelenítik, és beállítják a végleges cukortartalmat, végül palackozzák. A zárás ezeknél a pezsgőknél általában műanyagdugóval történik. Ide kapcsolható az olasz pezsgőgyártók körében elterjedt, de a Törleynél is alkalmazott spumante módozat, ami annyiban különbözik a hagyományos tartályos erjesztésű pezsgő készítési módszertől, hogy az alapbor helyett mustból történik a pezsgő erjesztése, nem borból.

Méthode Trans Vasée (korábban Méthode Classique néven használták), palackban erjesztett és érlelt pezsgő:

A pezsgő 1,5 literes, úgynevezett „magnum” palackokban erjed és érlelődik. A zárt rendszerű, hűthető, nyomásálló tartályba ürítés és a cukortartalom végleges beállítása után a seprőt szűréssel távolítják el. Ezután az újbóli palackozás során a kereskedelmi forgalomba kerülő palackokba töltik a pezsgőt.

Méthode Traditionnelle:

A pezsgő lezárva, $14{ }^{\circ} \mathrm{C}$ körüli hőmérsékleten, fekvő helyzetben, 2 - 3 évig ugyanabban a palackban erjed és érlelődik, mint amelyben később forgalmazzák. Az érlelés után a palackban lévő üledéket (seprőt) a pezsgőmesterek rázóállványon, szakavatott mozdulatokkal a dugóra rázzák, majd a palack nyakrészét $25^{\circ} \mathrm{C}$-os sóoldatba merítik. Az így keletkezett jégdugót a seprőtlenítés (르ogorzsálás) során a belefagyott seprővel együtt kilövetik. Ezután a pezsgő végleges cukortartalmát expedíciós likőrrel beállítják, a palackot parafadugóval és drótkosárral lezárják, címkézik, végül csomagolják. 
A projekt tárgyának a Method Charmant technológiával készülő pezsgő palackozását választottuk. A technológiai folyamattal kapcsolatos fontosabb információkat az 1. sz. táblázat tartalmazza.

\begin{tabular}{|c|c|c|c|c|}
\hline $\begin{array}{l}\text { Pezsgő- } \\
\text { előkészítő }\end{array}$ & Depalettázó & Mosó, öblítő & Töltőcsarnok & Palettázó \\
\hline \multicolumn{5}{|l|}{ Berendezések } \\
\hline $\begin{array}{l}\text { Saválló acél } \\
\text { vezetékhálózat }\end{array}$ & Villásemelő & Mosógép & Puffertartály & $\begin{array}{l}\text { Vákumfejes } \\
\text { berendezés }\end{array}$ \\
\hline Laboratórium & Görgősor & Öblítőgép & $\begin{array}{l}\text { Rozsdamentes } \\
\text { Acél } \\
\text { szállítószalag }\end{array}$ & $\begin{array}{l}\text { Kartonösszerakó } \\
\text { gép }\end{array}$ \\
\hline \multirow[t]{5}{*}{$\begin{array}{l}\text { Rozsdamentes } \\
\text { hűthető tartály }\end{array}$} & Futószalag & & Töltőgép & $\begin{array}{l}\text { Raklapösszerakó } \\
\text { gép }\end{array}$ \\
\hline & $\begin{array}{l}\text { Palackkirakó } \\
\text { gép }\end{array}$ & & Dugaszológép & Villásemelő \\
\hline & $\begin{array}{l}\text { Rekeszleszedő } \\
\text { gép }\end{array}$ & & $\begin{array}{l}\text { Lefuvató } \\
\text { berendezés }\end{array}$ & \\
\hline & & & Kupakológép & \\
\hline & & & Címkézőgép & \\
\hline \multicolumn{5}{|l|}{ Műveletek } \\
\hline $\begin{array}{l}\text { M1 } \\
\text { fém beoldódást } \\
\text { gátol }\end{array}$ & $\begin{array}{l}\text { M6 } \\
\text { görgősorra } \\
\text { tesz }\end{array}$ & $\begin{array}{l}\text { M11 } \\
\text { visszárus } \\
\text { palackot mos }\end{array}$ & $\begin{array}{l}\text { M14 } \\
\text { töltőgépet táplál }\end{array}$ & $\begin{array}{l}\text { M22 } \\
\text { palackot rekeszbe } \\
\text { tesz }\end{array}$ \\
\hline $\begin{array}{l}\text { M2 } \\
\text { oxigént kizár }\end{array}$ & $\begin{array}{l}\text { M7 } \\
\text { palackot } \\
\text { továbbít }\end{array}$ & $\begin{array}{l}\text { M12 } \\
\text { visszárus } \\
\text { palackot } \\
\text { fertőtlenít }\end{array}$ & $\begin{array}{l}\text { M15 } \\
\text { síkosító } \\
\text { anyaggal lát el }\end{array}$ & $\begin{array}{l}\text { M23 } \\
\text { csomagolást } \\
\text { biztosít }\end{array}$ \\
\hline $\begin{array}{l}\text { M3 } \\
\text { széndioxidot } \\
\text { megtart } \\
\text { (pezsgőnél) }\end{array}$ & $\begin{array}{l}\text { M8 } \\
\text { futószalagra } \\
\text { tesz }\end{array}$ & $\begin{array}{l}\text { M13 } \\
\text { steril palackot } \\
\text { öblít }\end{array}$ & $\begin{array}{l}\text { M16 } \\
\text { palackot tölt }\end{array}$ & $\begin{array}{l}\text { M24 } \\
\text { csúszást gátol }\end{array}$ \\
\hline $\begin{array}{l}\text { M4 } \\
\text { Minőség- } \\
\text { biztosítási } \\
\text { megfelelőséget }\end{array}$ & $\begin{array}{l}\text { M9 } \\
\text { rekeszből } \\
\text { palackot }\end{array}$ & & $\begin{array}{l}\text { M17 } \\
\text { dugót biztosít }\end{array}$ & $\begin{array}{l}\text { M25 } \\
\text { raklapot biztosít }\end{array}$ \\
\hline
\end{tabular}




\begin{tabular}{|c|c|c|c|}
\hline biztosít & kiszed & & \\
\hline \multirow[t]{4}{*}{$\begin{array}{l}\text { M5 } \\
\text { alapanyagot } \\
\text { megszűr }\end{array}$} & $\begin{array}{l}\text { M10 } \\
\text { palackot tárol }\end{array}$ & $\begin{array}{l}\text { M18 } \\
\text { penész- } \\
\text { mentességet } \\
\text { biztosít }\end{array}$ & $\begin{array}{l}\text { M26 } \\
\text { raklapot fóliáz }\end{array}$ \\
\hline & & $\begin{array}{l}\text { M19 } \\
\text { kapszulát } \\
\text { biztosít }\end{array}$ & $\begin{array}{l}\text { M27 } \\
\text { Továbbszállítást } \\
\text { biztosít }\end{array}$ \\
\hline & & $\begin{array}{l}\text { M20 } \\
\text { szimmetriát } \\
\text { biztosít }\end{array}$ & \\
\hline & & $\begin{array}{l}\text { M21 } \\
\text { címkét ragaszt }\end{array}$ & \\
\hline
\end{tabular}

1. táblázat: Információk a technológiai folyamatról

(Forrás: saját szerkesztés)

\subsubsection{A termékkel kapcsolatos igényelemzés}

A technológiai folyamat értékelemzésénél fontos, hogy a gyártósor által előállított termékkel szembeni igényeket is feltárjuk és csak ennek ismeretében vizsgáljuk magát a folyamatot.

A termékkel (pezsgő) szembeni igények a következők:

I1 Megfelelő alapanyagból készüljön

I2 Megfelelő széndioxid tartalmú legyen

I3 Biztonságos, nyomásálló palackban legyen

I4 A termékről a címke információt nyújtson

I5 Megfizethető legyen

I6 Hozzáférhető legyen

I7 Esztétikus legyen

I8 Megfelelő kiszerelésű legyen

I9 Megfelelő alkoholtartalmú legyen

I10 Szennyeződésmentes legyen

\subsubsection{A termékkel kapcsolatos funkcióelemzés}

A fogyasztói / felhasználói igényekből kiindulva, meghatározzuk először a termék, majd a technológia funkcióit. 
A termék (pezsgő) funkciói:

F0 Megfelelő ízt biztosít

F01 Meghatározott minőségű szőlőből készüljön

F02 Meghatározott termőtájról származzon a szőlő

F03 Megfelelő cukortartalommal rendelkezzen

F1 Megfelelő alkoholtartalmat biztosít

F2 Esztétikus legyen

F21 A palack formája tetszetős legyen

F22 A címke tetszetős legyen

F23 A pezsgő színe tetszetős legyen

F24 A pezsgő illata megfelelő legyen

F3 Szállíthatóságot biztosítson

F31 Biztonságos, nyomásálló palackban legyen

F4 Információt szolgáltasson a termékről

F41 A szőlőről, termőtájról információt adjon

F42 A szavatosságról információt adjon

F5 Szivárgásmentességet biztosítson

F6 Szennyeződésmentességet biztosítson

Az igényelemzés második lépése a technológiával szembeni elvárások elemzése. Mit és hogyan kell a technológiának tennie ahhoz, hogy a termékkel szemben megfogalmazott igényeknek maradéktalanul megfeleljen.

A technológiával szembeni igények a következők:

I1 Gátolja a fémek beoldódásának elkerülését

I2 Saválló acélból készüljenek a vezetékek

I3 Biztosítsa az oxigén kizárását és a széndioxid megtartását

I4 Nitrogéngázzal és széndioxidgázzal biztosítsa az alapanyag mozgatását

I5 Laboratóriumi vizsgálatokkal ellenőrizze a megfelelő minőséget

I6 Rozsdamentes anyagból készüljenek a tartályok

I7 A mosó adalék megfeleljen a környezetvédelmi szempontoknak

I8 Megfelelő nyomásállóságú palackba történjen a töltés

I9 Szűrje ki a sérült visszárus palackokat 
Megfelelően sterilizálja a palackokat

I11Síkosító anyaggal vonja be a szállítószalagot, hogy a palackok ne kopjanak, és ne csússzanak el

I12 A dugó megfelelő lezárást biztosítson

I13 Biztosítsa a szárazságot a penészmentesség érdekében

I14 Az esztétika érdekében szimmetrikusan helyezkedjenek el a címkék

I15 A címke tartalmazzon minden információt a termékről

I16 A kartonok biztonságos szállítást tegyenek lehetővé

A technológia funkcióelemzését az 1.sz. ábra tartalmazza.

A technológia funkcióit, berendezés - paraméter mátrixát a 2. sz. táblázat tartalmazza.

\begin{tabular}{|l|l|l|l|}
\hline Funkció & Berendezés & Paraméter & Érték \\
\hline $\begin{array}{l}\text { F63 Tartályt folyamatosan } \\
\text { alapanyaggal látja el }\end{array}$ & Puffer tartály & Űrtartalom & 5000 liter \\
\hline $\begin{array}{l}\text { F21 Oxigénmentességet } \\
\text { biztosít }\end{array}$ & $\begin{array}{l}\text { Zárt } \\
\text { vezetékhálózat }\end{array}$ & Anyaga & Saválló acél \\
\hline $\begin{array}{l}\text { F24 Alapanyagot palackba } \\
\text { juttat }\end{array}$ & Töltőgép & $\begin{array}{l}\text { Töltőszár } \\
\text { Kapacitás }\end{array}$ & $\begin{array}{l}100 \mathrm{db} \\
10000 \text { palack/óra }\end{array}$ \\
\hline F5 Palackot továbbít & Szállítószalag & Anyaga & Rozsdamentes acél \\
\hline F82 Palackot mos & Mosógép & Mosási hőfok & $85-90 \mathrm{C}$ \\
5000 üveg
\end{tabular}

2. táblázat: Funkció-berendezés-paraméter mátrix

(Forrás: saját szerkesztés)

\subsubsection{A funkcióhordozók és költségeinek meghatározása}

A funkcióhordozók költségeit 80.000 palack/műszak mennyiségre határoztuk meg. Információk a technológia folyamat költségeiről:

Egy műszak alatt a gépsor 80.000 palackot termel. A technológia költségeit a 3. sz. táblázat tartalmazza.

\begin{tabular}{|l|l|l|l|}
\hline Sorszám & Költség neve & Költség \% & Megjegyzés \\
\hline 1. & Bérköltség & 0,1460 & \\
\hline 2. & Alapanyagköltség & 36,0000 & Szőlő \\
\hline 3. & Adalékanyagok & 3,8000 & \\
\hline
\end{tabular}




\begin{tabular}{|l|l|l|l|}
\hline 4. & Közvetett költségek & 38,0000 & \\
\hline 5. & Üzemi általános költség & 19,0000 & \\
\hline 6. & Elektromos áram költsége & 0,0096 & \\
\hline 7. & Vízfelhasználás költsége & 0,0380 & \\
\hline 8. & Karbantartási költség & 0,9600 & \\
\hline 9. & Gépóraköltség & 0,9600 & \\
\hline 10. & Csomagolási költség & 0,9600 & \\
\hline Összesen: & & 100,0000 & \\
\hline
\end{tabular}

3. táblázat: A technológiai folyamat költségei

(Forrás: saját szerkesztés)

\subsubsection{Költségkritikus pontok}

A vizsgálat alapján az alábbi funkciók kerültek ki költségkritikus pontokként:

F8 „Mosást végez funkció” a felhasznált víz és mosó-, a fertőtlenítő adalék költsége, valamint a palack válogatásához felhasznált munkaerő költsége miatt. A visszárus palackok közül sok a selejt. A funkcióköltség a költségek 11\%-át teszi ki.

F2 „Biztonságos töltést végez funkció” a költségek 9 \%-át teszik ki.

F10 „Palackot tárol funkció” a költségek 6 \% - át teszik ki.

Funkciókritikus pont:

F81 Palackot válogat funkció az emberi erőforrás kapacitása miatt.

F10 Palackot tárol funkció a nem megfelelő tárolás miatti selejtek miatt.

\subsubsection{Javaslatok a technológiai folyamat fejlesztésére (részlet)}

Az ötletek gyűjtése során nagyszámú változatot fejlesztettünk ki, amelyek közül néhányat a következőkben mutatunk be.

\section{1. ötlet: selejt csökkentése}

Jelenleg a cégnél az üres, töltésre váró palackokat az udvaron, szabadon tárolják. Ennek következtében a göngyölegek ki vannak téve az időjárás viszontagságainak, a hideg és meleg váltakozása, az eső és a hó hatására elég sok palack megsérül. A veszteség anyagi károkat okoz, mely kiküszöbölhető lenne egy fedett tároló építésével. Ez megoldható lenne egy könnyűszerkezetes épület létrehozásával, mely nem igényelne sem fütést, sem egyéb különleges eljárást. Viszonylag alacsony költségű beruházást igényelne, a megtakarítás azonban jelentős lehetne. A fedett tároló az üvegek szennyeződését is mérsékelné. 


\section{2. ötlet: visszaváltható palackok megszüntetése}

Költségcsökkentő megoldást jelentene a visszaváltható palackok megszüntetése. Környezetvédelmi szempontból ez akkor lenne megfelelő, ha egyre többen tartanák be a szelektív hulladékgyűjtés szabályait, így a használt üvegeket újra lehetne hasznosítani. A termelésben újra felhasznált palack ismételt alkalmazása azonban gazdaságtalan. Egyrészt sok a használhatatlan göngyöleg, előfordul kiszedhetetlen szennyeződés (pl. dugómaradék), illetve sérültek is lehetnek, ezeket pedig újra felhasználni már nem lehet. Az ép palackok mosása, fertőtlenítése sok pénzt igényel, az ehhez felhasznált vegyszerek és a mosóvíz melegítéséhez szükséges hőenergia károsak a környezetre, új üvegekkel ezek a problémák is kiküszöbölhetőek lennének. Növeli a költségeket továbbá, hogy az üzletekből a használt palackokat vissza kell szállítani a céghez. Ez két lépcsőben történik, egyszer egy központba viszik az üzletből, majd a központból kerül vissza az üzembe. Az ötlet hatékony megvalósítását akadályozza az a tény, hogy a jelenlegi törvényi szabályozás kötelezi a gyártót az üres palackok visszavételére. Ennek ellenére az a véleményünk, hogy a használt palackok ismételt felhasználását modernizálni kell.

\section{3. ötlet: palack válogatásához használt emberi munkaerő felváltása gépekkel}

Szintén a mosási fázist javíthatná egy olyan berendezés beszerzése, amely érzékeli a palackok sérüléseit, a bennük található szennyeződéseket és azokat automatikusan kiválogatja. Ilyen berendezés létezik, úgynevezett „szimat”-ként emlegetik. A gép használatával emberi munkaerőt lehetne kiváltani, azonban a beruházás meglehetősen költséges.

\subsubsection{Eredmények}

A funkcióelemzés és a funkcióköltségek meghatározása lehetővé tette, hogy a team feltárja a funkcióban és költségben „gyenge” pontok meghatározását. Az elemző munka azt is feltárta, hogy tovább kell vizsgálni a technológiai folyamatot. A nagy kereskedelmi hálózatok milliós megrendelést is hajlandók feladni ugyan, de megkövetelik a pontos szállítási határidőt és az azonos minőséget. Ez esetenként nehéz feladat. Folyamatosan kell biztosítani a szőlő azonos minőségét, amely elvezet a szőlőtermelés technológiájához is. Ennek a követelménynek meg kell jelennie a pezsgőtermelő és a szőlőtermelő szerződésében is. Szükség van a folyamatos együttműködésre. A magyar élelmiszeripar létéhez hozzátartozik a gazdaságos export, amely megvalósításában az értékelemzés jelentős segítséget nyújthat.

\section{Az új menedzsment módszerek alkalmazásának problémái}

A menedzsment területén megjelentek olyan eljárások is, amelyeket a cég soha nem végzett, és "gyanakodva" fogadja a nehezen hihető hatékonyságnövekedési ajánlatokat (például TRIZ, értékelemzés). Azért is nehéz „eladni” ezeket az ismereteket, mert a vállalatok ilyen megoldásokkal még nem találkozott. Ezért van hatalmas jelentősége a felsőfokú intézmények ilyen jellegű tevékenységének, mert a fiatalabb generáció már tájékoztatni tudja a vezetést az egyes lágytudományos módszerek fontosságáról, lehetséges alkalmazási területeiről, a várható eredményekről stb. 
A tudásterület elkülönülése megjelent ezen területek szakértőin keresztül, akik általában - nagyfokú elméleti és gyakorlati tudásuk alapján - viszonylag rövid idő alatt ki tudják alakítani az adott gazdálkodási egységnél azokat a megoldásokat, amelyek az erőforrások jobb hasznosulását teszik lehetővé.

A tudományterület elkülönülése megjelent az egyetemek és főiskolák tanterveiben és tantárgyi tematikáiban. Egyes menedzsment módszerek önálló diszciplínák kereteit vették fel, amelyek a tanárok szakosodását is szükségessé tették. A tudás és tudományterületek elkülönülését szakmai szervezetek is jelzik.

Az új menedzsment módszerek alkalmazásával kapcsolatban a probléma úgy merül fel, hogy a szakértővé válás általában több éves „kemény” munkát igényel. A speciális képzés jellemzően magas költséggel jár, a magánszemélyek többségének ez anyagi nehézséget jelent. A felsőoktatási intézmények - sajátos képzési tevékenységük miatt - csak a szakmai alapismereteket tudják közvetíteni, a „profivá” válás már sokkal nehezebb feladat.

Megítélésünk szerint az új menedzsment módszerek és eljárások jelentik az új technikai gazdálkodási forradalmat. Azért iktattuk be a „gazdálkodási” szót, mert ezek az eljárások gyakran igen gyorsan növelik a működés hatékonyságát - még a nem profit - orientált szervezeteknél is. Viszonylag kis ráfordítással a magyar gazdaság jelentős erőforrástöbblethez juthatna, ha a politikai - gazdasági vezetés felismerné a menedzsment módszerek jelentőségét.

\section{1. Összefoglalás}

A jelen időszak problémakezelése új megközelítést igényel a sikeres megoldás megtalálása érdekében. A döntéshez szükséges optimalizálási számítások feltételrendszerének tartalmi elemeiben nemcsak a pénzügyi, gazdasági feltételek, hanem környezeti, társadalmi (nem pénzügyi, de számszerűsíthető) feltételeinek szerepeltetése is elengedhetetlen, mivel ez hosszútávon kedvezőbb eredményeket teremthet. Az új megközelítésben, illetve a hatékonyabb megoldások felkutatásában jelentős szerepet játszhatnak az új menedzsment módszerek, ezen belül az értékmódszertan alkalmazása. A gazdaságilag fejlett országokban (USA, Japán, EU stb.) már jelentős eredményeket értek el a különböző műszaki - gazdasági problémák hatékony megoldásában - az értékmódszertan alkalmazásával. Magyarországon az értékmódszertan széles körű alkalmazásához az előfeltételek rendelkezésre állnak, a SAVE International (Amerikai Értékelemzők Nemzetközi Társasága) támogatásával világszínvonalú magyar szakértői gárda jött létre.

\section{Hivatkozások}

[1] G. S. Altsuller, B. L. Zlotin, V. I. Filatov (1985), Professija - Poisk novova (Új keresési szakma), Kisinyov, Kartyja Moldovencke

[2] P. Á. Bod (2001), A pénz világa - a világ pénze, K.J.K. - KERSZÖV Jogi és Üzleti Kiadó Kft., Budapest, 1-316. old.

[3] C. W. Bytheway (2007), FAST Creativity \& Innovation, J. ROSS PUBLISING, USA 
[4] J. J. Kaufman, R. Woodhead (2006), Stimulating Innovation in Products and Services with Function Analysis and Mapping, WILEY INTERSCIENCE, USA

[5] F. Nádasdi, M. Haranginé Csomós (1993), A REFA bevezetésének helyzete és eredményei az iparban, Ipari Szemle, XIII. évfolyam, 1993/6. szám, 60-62. old.

[6] E. D. Parker (1994), Management Application of Value Engineering for Business and Government, The Lawrence D. Miles Foundation, Washington, D.C.

[7] Pezsgőgyártás értékelemzése. Esettanulmány. Témavezető: Dr. Nádasdi Ferenc, a team tagjai: Diós Ágnes, Lajkóné Pléli Beáta, Nyuliné Jákli Erika. Dunaújvárosi Főiskola, Dunaújváros, Magyarország. 2012.

[8] Y. Sato, J. J. Kaufman (2005), Value Analysis Tear - Down: A New Process for Product Development and Innovation, Industrial Press Inc. and Society of Manufacturing Engineers, New York, USA

[9] R. B. Stewart (2005), Fundamentals of Value Methodology, Xlibris Corporation, USA

[10] www.triz.org

[11] www.triz-journal.com 